\title{
Self subcutaneous injection of profenophos with delayed systemic toxicity: a case report
}

\author{
R. Hanushraj ${ }^{1}$, S. Sudharsan ${ }^{2}$ \\ ${ }^{1}$ Dr. R. Hanushraj, Post Graduate in General Medicine, ${ }^{2}$ Dr. S. Sudharsan, Professor of Medicine; both authors are \\ affiliated with Rajah Muthiah Medical College, Annamalai University, India.
}

Address for Correspondence: Dr. R. Hanushraj, Post Graduate in General Medicine, Rajah Muthiah Medical College, Annamalai University. Email id: hanu4g@gmail.com

\begin{abstract}
Suicidal poisoning by ingestion of organophosphate (OP) insecticide is a common mode of poisoning in our region. However, attempted suicide via the parenteral route has rarely been reported. We report a case of self subcutaneous injection of $50 \%$ profenophos in both hands, a rare and unusual way of intoxication. It causes local toxicity such as toxic cellulitis, abscess and necrosis with delayed systemic toxicity. He responded to parental antibiotics, surgical debridement, atropine and pralidoxime.
\end{abstract}

Key-words: subcutaneous injection, organophosphate, surgical debridement.

\section{Introduction}

Organophosphorous compound among the most popular and most widely used insecticide in India. Because of its easy availability and assess organophosphorous poisoning is very common. Poisoning occur mostly by voluntary ingestion, inhalation or by absorption by skin. Only few case report of parental organophosphorous poisoning have been described $[1,2,3,4]$. We are reporting a case of self subcutaneous injection of organophosphorous with atypical systemic manifestation and severe local toxicity, which is an uncommon mode of organophosphorus poisoning, managed in our hospital. He injected $50 \%$ profenophos in both hands.

\section{Case Report}

A 50 year old male, insecticide shopkeeper by occupation presented to emergency room with history of self injection of $50 \%$ profenofos, $2 \mathrm{ml}$ each in dorsal aspect of both hands. The exposure occurred 20 hours before presentation. On presentation he had a complaint of giddiness and swelling with pain in both hands.

The pain had made him to seek medical attention. He had no premorbid illness. He consumes alcohol. On examination: $\mathrm{He}$ is conscious, oriented and comfortable. Pulse: 88/min regular, BP: 110/80 mmHg, RR: 18/min regular, SpO2: 99\% room air, No pallor, No cyanosis, No clubbing, and No icterus. Cardio vascular system: S1S2 heard, no murmur, JVP not raised.

Respiratory system: Bilateral equal air entry, no added sound. Central nervous system: Pupil 3 mm equally reacting to light on both sides, no excessive salivation, no excessive lacrimation, no loose stools, no fasciculation, power 5/5, tone normal, deep tendon reflexes 2+, plantar bilaterally flexor. Abdomen: soft, non tender, organs not palpable, bowel sound were heard. Local examination of both hand showed swelling with erythema extending up to mid one third of forearm on both upper limb. There was cicatrix of around $3 \mathrm{~cm}$ in diameter on dorsal aspect of right hand and around $1 \mathrm{~cm}$ in diameter on dorsal aspect of left hand.

Manuscript received $26^{\text {th }}$ June 2016

Reviewed: $10^{\text {th }}$ July 2016

Author Corrected: $20^{\text {th }}$ July 2016

Accepted for Publication $3^{\text {rd }}$ August 2016 


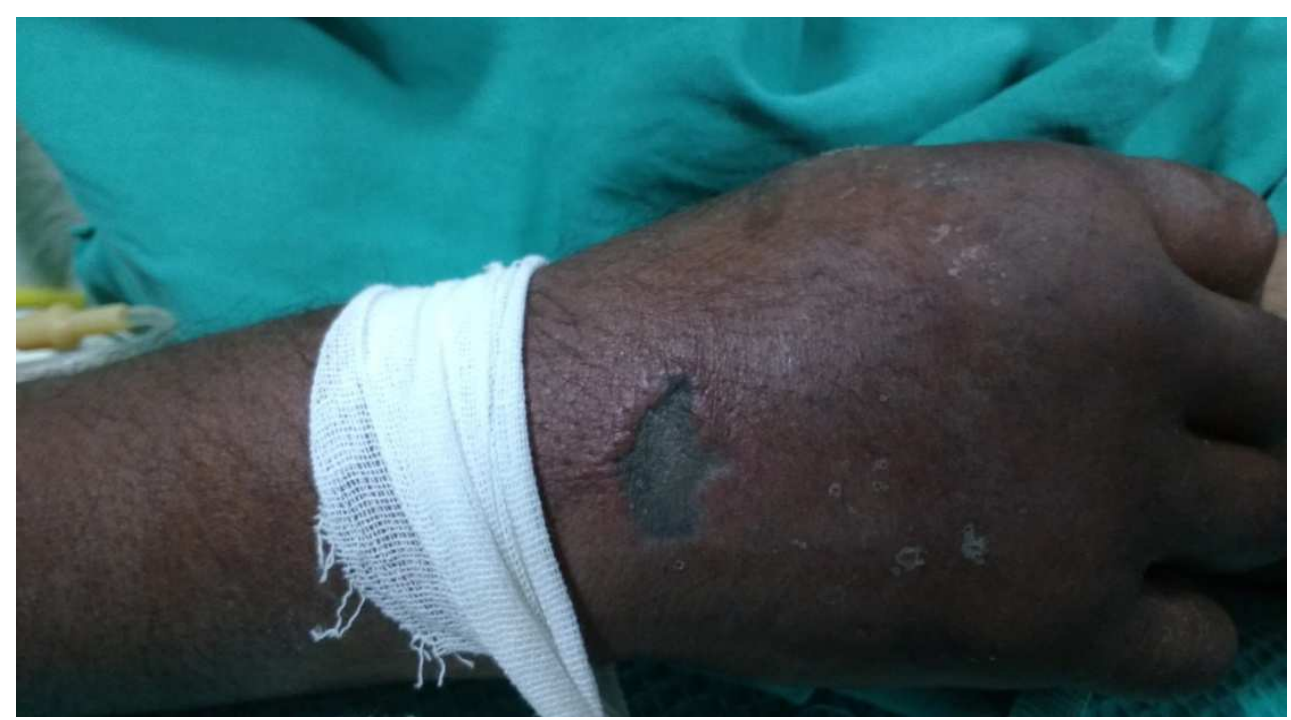

Fig 1: Day 1 - Right hand with swelling and erythema with cicatrix at the injection site.

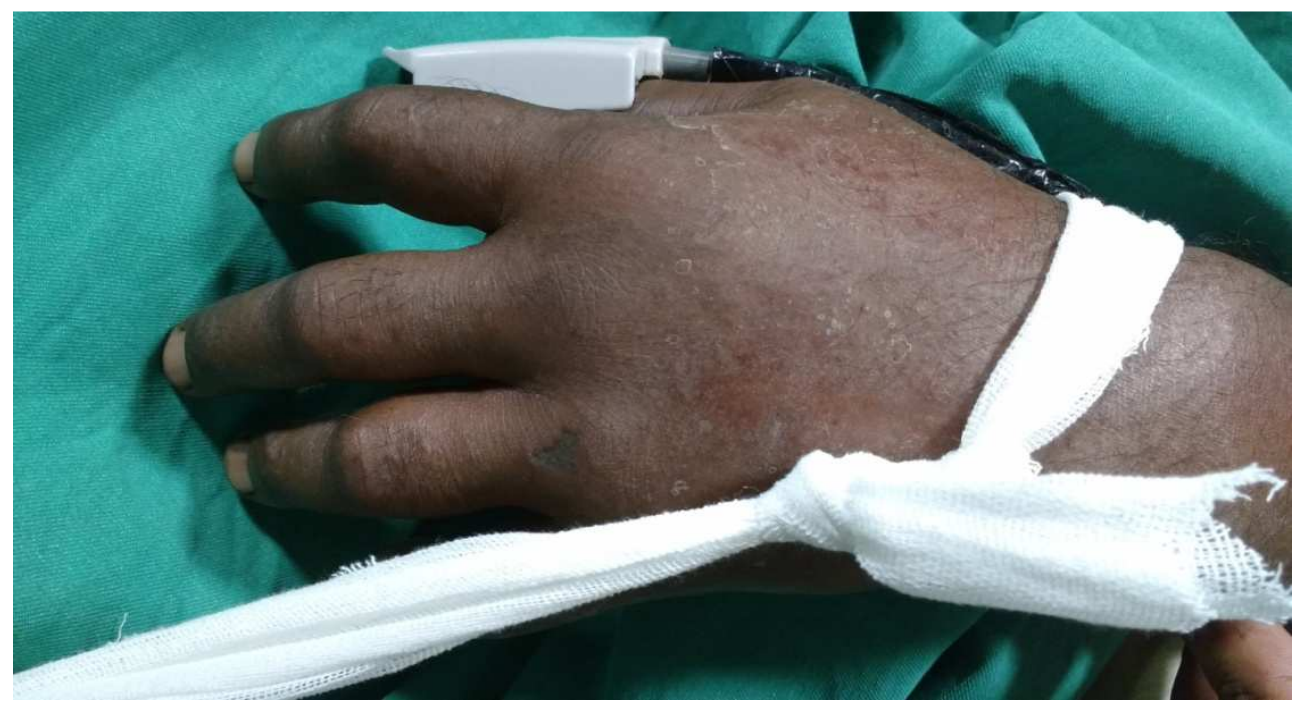

Fig 2: Day 1 - Left hand with swelling and erythema with cicatrix at the injection site.

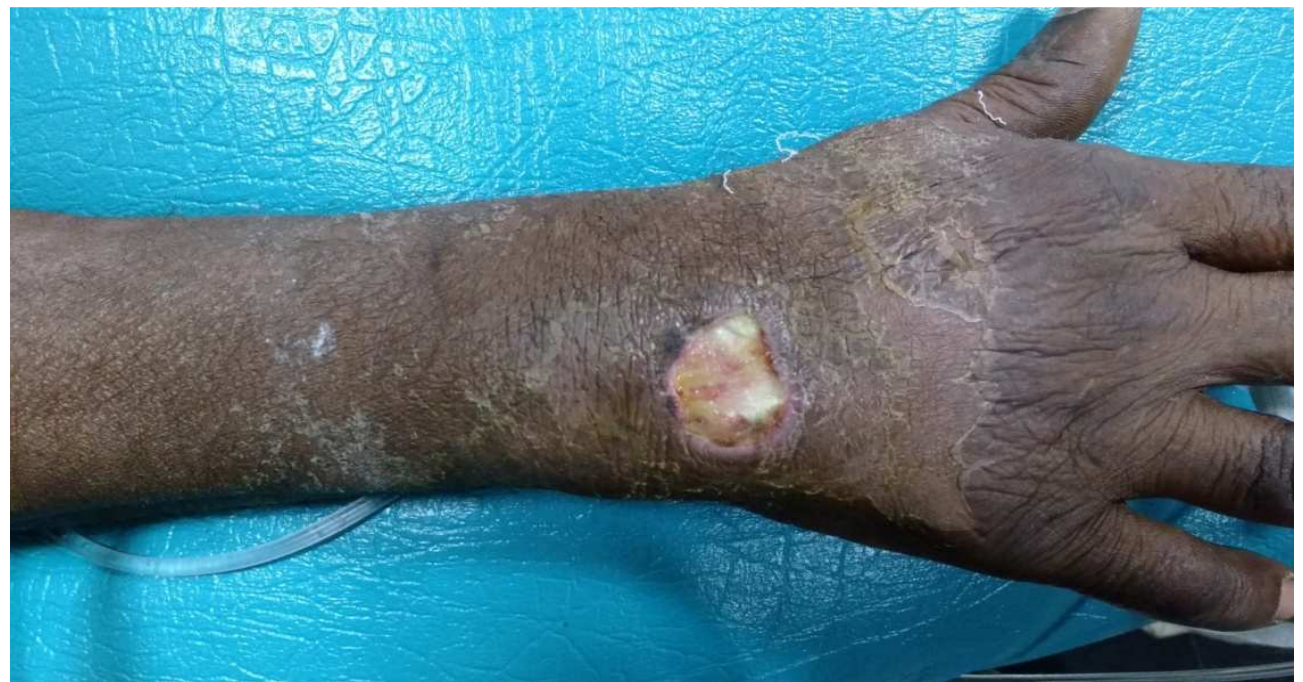

Fig 3: Right hand two days after surgical debridement. 


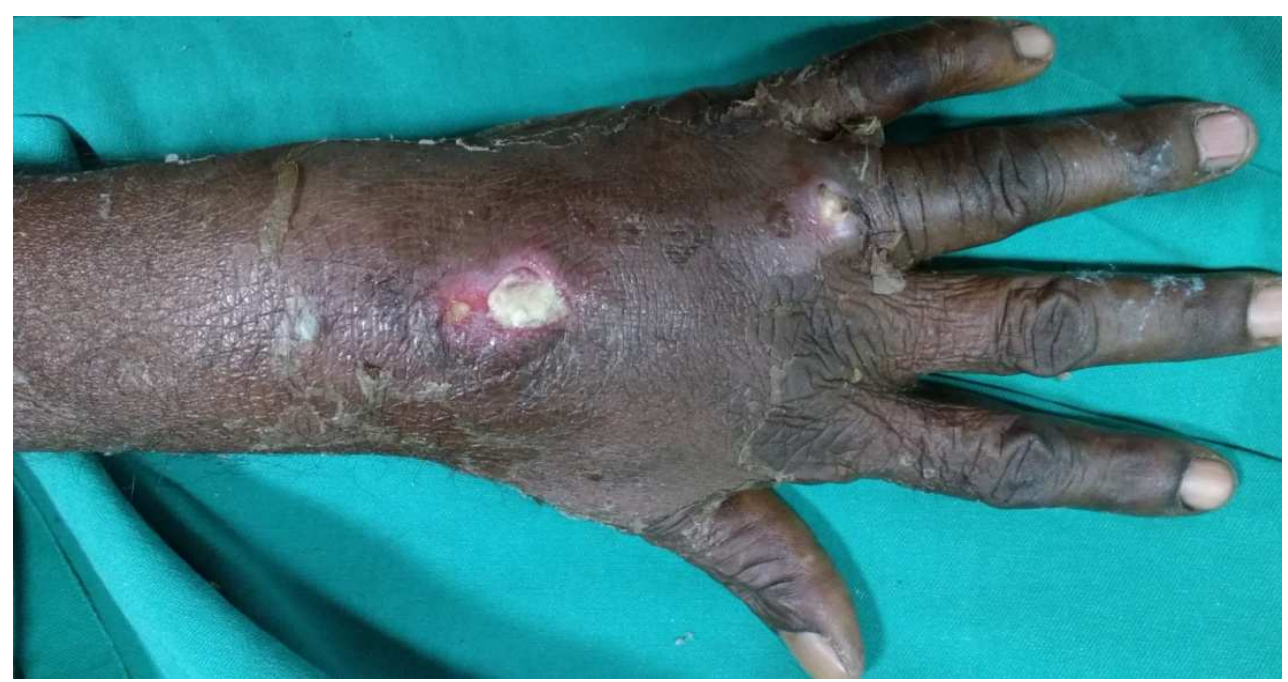

Fig 4: Right hand two days after surgical debridement.

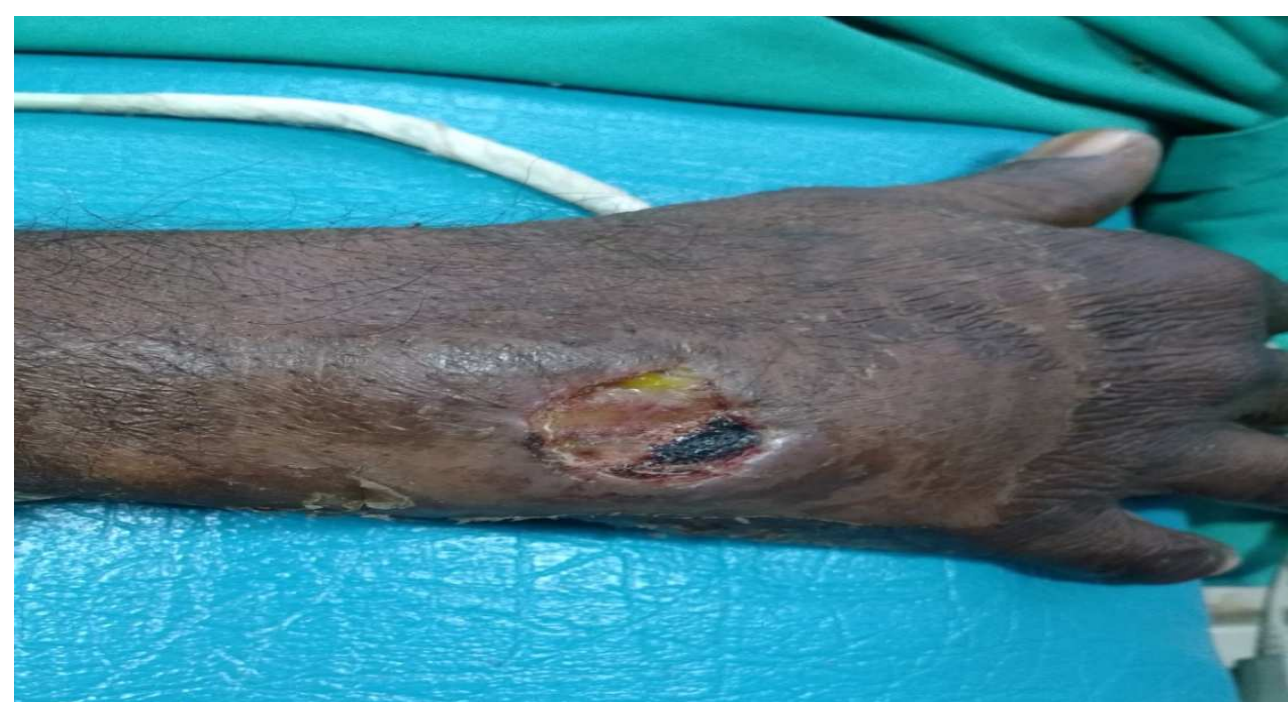

Fig 5: On day of discharge - right hand.

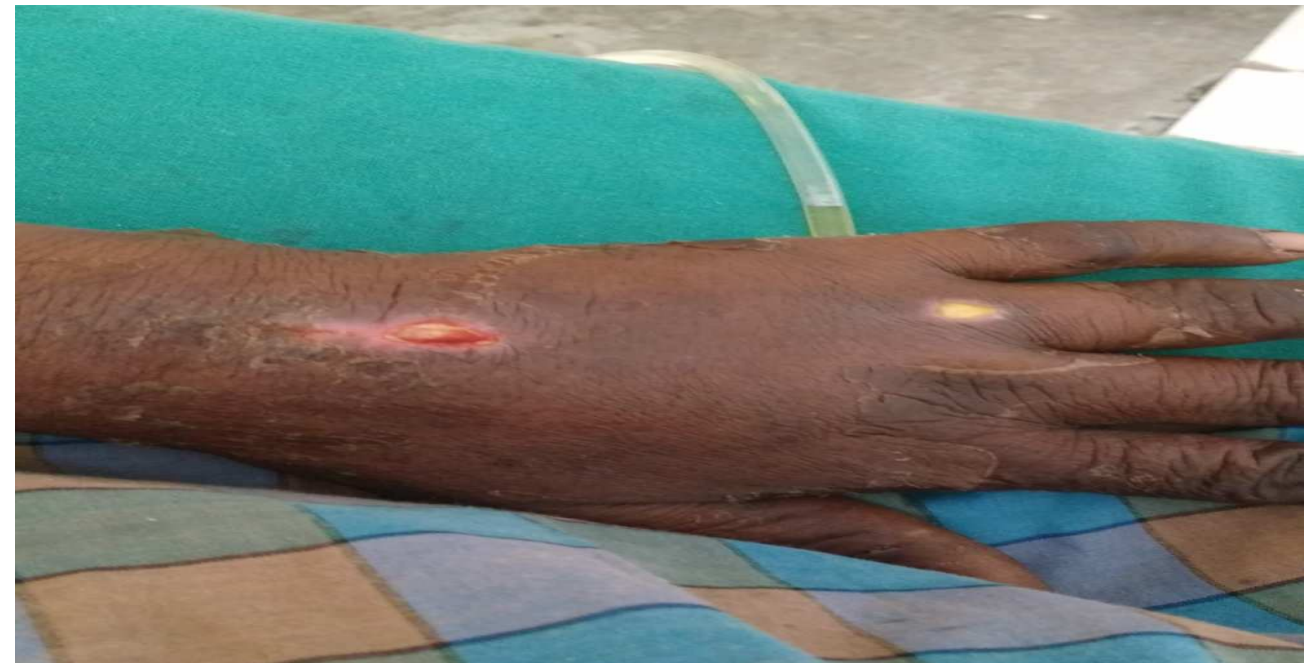

Fig 6: On day of discharge - left hand. 
His investigations on admission showed $\mathrm{Hb}: 10.7 \mathrm{gm} \%$, WBC 10800cells/mmcu, lymphocytes $15 \%$, neutrophils $82 \%$, RBS 3980cells/mmcu, urea 20mg/dl, creatinine 0.9mg/dl, Na 140mmol/1, K 4.7mmol/L, Serum cholinesterase 4800 U/L (normal 5100 - 11700 U/L). Chest X-ray: Normal cardiac and lung shadow, ECG: within normal limit.

He was admitted in ICU and was started on Inj.Ceftriaxone+sulbactum, inj. Metronidazole, inj. Thiamine, inj pralidoxime and IV fluids. Though the patient didn't have cholinergic signs and symptoms on presentation, on reviewing literature parenteral opc poisoning are prone for delayed manifestations [4], he was added on with inj atropine 1mg iv every $15 \mathrm{~min}$. He developed atropine delirium after 12 hours of starting atropine and atropine dose was tapered and stopped on $3^{\text {rd }}$ day. The swelling was progressive till the second day of admission. On $3^{\text {rd }}$ day of admission surgical debridement of necrosed tissue were done and pus was drained. Following the swelling was regressive. The antibiotics were continued. Swelling resolved completely on $5^{\text {th }}$ day and debrided wound was healing well. On $6^{\text {th }}$ day of admission he developed wheeze and crackles, pupil were $1 \mathrm{~mm}$ on both sides with minimal reaction to light, there was no muscle weakness, his serum cholinesterase was found to be $643 \mathrm{U} / \mathrm{L}$ and there were no other muscarinic and nicotinic signs or symptoms. Inj. atropine $2 \mathrm{mg}$ IV bolus was given and atropine infusion was started at a rate of $4 \mathrm{mg} / \mathrm{hr}$. The wheeze and crackles subsided with atropine. Serum cholinesterase was rising on subsequent days. Serum cholinesterase was found to be $2584 \mathrm{U} / \mathrm{L}$ on $11^{\text {th }}$ day. Patient was discharged on $13^{\text {th }}$ day of hospital stay and the wound was healing well.

\section{Discussion}

Organophosphates are powerful inhibitors of acetylcholinesterase which is responsible for hydrolyzing acetylcholine to choline and acetic acid after its release and completion of function (i.e. propagation of action potential). As a result, there is accumulation of acetylcholine with continued stimulation of cholinergic receptors and eventual paralysis of nerve or muscle [5]. Cholinergic crisis usually occurs within the first 8 hours and nearly all within 24 hours [6].

The initial treatment of poisoning focuses on ensuring adequate oxygenation, followed by the administration of atropine to antagonize the muscarinic and central nervous system effects of the OP. Pralidoxime is usually used in the case of respiratory depression, muscle fasciculations or muscular weakness to antagonize the toxicity of OPs on nicotinic synapses. The dose of atropine and pralidoxime should be controlled flexibly. In reviewing literatures parenteral organophosphorous poisoning is highly toxic especially in intravenous and intramuscular poisoning and they are prone to develop delayed systemic toxicity. Even a case of intermediate syndrome has been reported by Ashok Badhe et al following intravenous organophosphorous poisoning [1].

In the present case, signs and symptoms of systemic toxicity (cholinergic crisis) resulting from the subcutaneous injection of organophosphorous manifested late, $6^{\text {th }}$ day of hospital stay. And the patient had fluctuating serum cholinesterase level, where maximal fall in serum cholinesterase observed during regressing of swelling. Which may due to transient release of organophosphorous compound from injection site.

\section{Conclusion}

This case represents a rare mode of organophosphorous administration for suicide. The patient had immediate local toxic effects which may be due to the contaminated needle or solvent of organophosphorous and delayed systemic toxicity which may be contributed by transient release of organophosphorous compound from subcutaneous tissue. Antidote may be considered while debrideding the wound to counteract the release of OP from tissues. As intermediate syndrome is common among parenteral OP poisoning pralidoxime may play a very significant role in parenteral OP poisoning [4]. Parenteral organophosphorous poisoning are prone for delayed systemic effects and patients need prolong vigilant observation.

Funding: Nil, Conflict of interest: None initiated, Permission from IRB: Yes

\section{References}

1. Badhe A, Sudhakar S. An intravenous organophosphate poisoning with intermediate syndrome: An unusual way of intoxication. Indian $\mathbf{J}$ Critical Care Medicine. 2006; 10:191-92. [http: // www. bioline.org. $\mathrm{br} / \mathrm{pdf} ? \mathrm{~cm} 06026]$

2. Shrestha B, Shakya R, et al. Subcutaneous organophospate poisoning- A case report. $J$ 
Psychiatrists' Association of Nepal. Vol.2, No.2. 2013:46-48. [http://www.nepjol.info/index.php /JPAN/ article/download/9727/7995]

3. Sergio de Andrade Nishioka. Parentral injection of organophosphorous insecticide. Apros of two cases. Sao Paulo Med. J. Vol. 112 no. 2 Sao Paulo Apr/June 1994 [http://www.scielo.br/scielo.php?script=sci_arttext\&pid $=$ S1516-31801994000200008]

4. Sangeetha KP et al. International journal of clinical cases and investigations. Volume 5 (Issue 3 ). $1^{\text {st }}$
October 2013. 99:1056. [http:// www. ijcci.info/issueindex/volume-5-issue-3/216-case-report/313-parenteralorganophosphorous-poisoning-a-case-series-? showall $=1]$

5. Pillay VV (2013). "Modern medical toxicology", New Delhi: Jaypee Brothers Medical Publishers (P) LTD.

6. Judith E. Tintinalli (2011). “Tintinalli's emergency medicine $-7^{\text {th }}$ edition". New Delhi: The McGraw-Hill Companies, Inc: $1298-1300$.

\section{How to cite this article?}

R. Hanushraj, S. Sudharsan. Self subcutaneous injection of profenophos with delayed systemic toxicity: a case report. Int J Med Res Rev 2016;4(8):1420-1424.doi:10.17511/ijmrr.2016.i08.22. 